\title{
Acquired cystic disease-associated renal cell carcinoma
}

INSERM

\section{Source}

INSERM. (1999). Orphanet: an online rare disease and orphan drug data base. Acquired cystic disease-associated renal cell carcinoma. ORPHA:404514

Acquired cystic disease-associated renal cell carcinoma is a rare subtype of renal cell carcinoma, ocurring in the context of end-stage kidney disease and acquired cystic kidney disease, characterized by a usually well circumscribed, solid, multifocal, bilateral tumor with inter- or intracellular microlumen formation (leading to cribiform architecture). Tumors are often diagnosed incidentally in early stages, although complications caused by renal cysts (dull flank or abdominal pain, fever) or renal parenchymal bleeding may mask the underlying neoplastic process. Most have an indolent behavior. 